\title{
THE FATE OF INTRAVENOUSLY INJECTED GELATIN IN HUMAN SUBJECTS ${ }^{1}$
}

\author{
By WILLIAM S. HOFFMAN AND DONALD D. KOZOLL 2 \\ (From the Hektoen Institute for Medical Research of the Cook County Hospital and from the \\ Departments of Surgery of the Cook County Hospital and the Northwestern \\ University Medical School, Chicago)
}

(Received for publication October 10, 1945)

The value of specially prepared gelatin solutions for intravenous infusion as a plasma substitute in the treatment of shock caused by trauma or hemorrhage is now well recognized. Previous papers from our laboratory ( 1 to 3 ) have reviewed the literature on the subject and have presented findings indicating the effectiveness of such solutions in various types of shock encountered in human subjects in a large general hospital. These reports have demonstrated that intravenously injected gelatin is an effective and innocuous hemodiluting agent not only in patients with shock but in the relatively normal "hospital control" subjects.

The present investigation was undertaken to determine the fate of intravenously injected gelatin; the plasma levels achievable; the distribution of gelatin in the blood, tissues, and urine; and the rate of gelatin excretion. An effort was made also to determine to what extent the rate of excretion of gelatin varied with preparations of varying molecular weight.

\section{PLAN OF STUDY}

The gelatin preparations ${ }^{8}$ used in this study were all 5 per cent solutions of osseous gelatin prepared by electrodialysis of calcium gelatinate. They were of three stages of degradation. Lots No. $39,45,65$, and 80 were highly degraded gelatins prepared by twice autoclaving for 30 minutes at 15 pounds pressure. These had broad ultracentrifuge patterns and relatively low viscosity. Their weight average molecular weight was of the order of

1 The studies on which this paper is based were aided by a grant from the Upjohn Company, Kalamazoo, Michigan.

2 Abbott Fellow in Surgery, Northwestern University Medical School.

3 The gelatin solutions were kindly furnished by the Upjohn Company. They came in liter bottles prepared for direct use in intravenous infusions. They contained no preservative. The weight average molecular weight $\left(M_{w}\right)$ of the various lots were determined by the Upjohn Company from the intrinsic viscosity $\left(H_{0}\right)$ by the method
37,000 . It was this type which had been used exclusively in the previous studies from this laboratory and which had been found clinically effective. Lots No. 58-10, 83, and 93 were much less degraded. They were prepared by autoclaving for 20 minutes at a pressure of 10 pounds. Their weight average molecular weight was of the order of 58,000. Lots No. 58-15 and 101 were intermediate with a weight average molecular weight of the order of 47,000 . They were autoclaved for 20 minutes at 15 pounds pressure. All of these solutions, it should be recognized, including the least degraded, remained liquid at room temperatures. The latter were slightly more degraded than the Knox preparation employed by Koop (5) and others, which is gelled at room temperatures and must be warmed to body temperature before utilization.

To avoid cumbersome repetition, the least degraded preparations used in this study will be spoken of as heavy gelatin; the most highly degraded, as light gelatin; and the intermediately degraded, as intermediate gelatin.

All preparations except one were in physiological saline solution; Lot No. 39 was 5 per cent gelatin in 5 per cent dextrose solution. These solutions were stable at room temperatures showing no discoloration or other change even after a year. The older as well as the fresh preparations, as in previous studies, produced no reactions, except in the case of one lot (Lot. No. 80), which produced mild pyrogenic reactions that could not be attributed to faulty tubing or glassware.

The subjects chosen for this study were so called hospital controls, patients in the convalescent stage of illnesses not likely to produce appreciable changes in cardiac, circulatory, or renal function. They were for the most part patients recuperating from herniorrhaphy. All were

of Scatchard et al. (4). These values are listed in the following table:

\begin{tabular}{lcc}
\multicolumn{1}{c}{ Lot. No. } & $H_{\bullet}$ & $M_{\text {wo }}$ \\
B20610-39 & 0.2202 & 37,266 \\
B20610-45 & 0.2100 & 35,532 \\
B20610-65 & 0.2176 & 36,820 \\
B20610-80 & 0.2248 & 38,040 \\
B20610-58-15 & 0.2853 & 48,270 \\
B20610-101 & 0.2683 & 45,400 \\
B20610-58-10 & 0.3345 & 56,600 \\
B20610-83 & 0.3391 & 57,000 \\
B20610-93 & 0.3502 & 59,254
\end{tabular}

For the sake of convenience, the prefix B20610 - will be omitted in references to the individual lots. 
males. In a preliminary study a group of 24 subjects were given $2000 \mathrm{ml}$. of 5 per cent gelatin and the blood and urine gelatin concentration determined after the injection of $1000 \mathrm{ml}$. and after $2000 \mathrm{ml}$., and at 24, 48, 72, and 96 hours. Later, it was recognized that a much better insight into the fate of the injected gelatin could be obtained by the following procedure: At 9 a.m. (some 2 hours after breakfast), a control sample of blood was obtained and the patient was asked to empty his bladder. Then $1000 \mathrm{ml}$. of 5 per cent gelatin were injected at the usual clinical speed of about $330 \mathrm{ml}$. per hour. At the end of the injection, a blood sample was taken and the accumulated urine collected without catheterization. Then blood and total urine samples were collected at 2 hours, 4 hours, and 6 hours after the end of the injection, and again at 24, 48, 72 and at times 96 and 120 hours after the start of the injection. Gelatin and creatinine determinations were made on all blood and urine samples, thus a comparison of creatinine and gelatin clearances was possible. Besides, the 24 -hour creatinine excretions served as a check on the completeness of the urine collections. Those experiments in which there was some doubt as to the accuracy of the collection were discarded. Since the data in the 24-hour preliminary experiments in which $2000 \mathrm{ml}$. of gelatin were injected do not lend themselves to the same type of analysis as the later experiments, they will not be presented. It should be mentioned, however, that the injection of $2000 \mathrm{ml}$. was as innocuous as that of $1000 \mathrm{ml}$. and that the general findings in these experiments, both as to blood levels and rates of excretion, were consonant with the 42 more complete later experiments.

Gelatin was determined in blood and urine by the method of Janota (6) as follows: the total nitrogen (TN) was first determined by micro Kjeldahl method with distillation and microtitration. From this value was subtracted the gelatin plus non-protein (GN) obtained by Kjeldahl determination of a trichloroacetic acid filtrate. The difference is the albumin and globulin nitrogen. The non-protein nitrogen (NPN) was determined in an alcohol filtrate. The albumin and non-protein nitrogen (AN) was obtained by analysis of a filtrate obtained by addition of 21 per cent sodium sulfite (7). Thus

$$
\begin{aligned}
& T N-G N=\text { Serum Protein } N \\
& A N-N P N=\text { Albumin N } \\
& \text { GN }- \text { NPN }=\text { Gelatin N } \\
& \text { Serum Protein } N-\text { Albumin } N=\text { Globulin } N .
\end{aligned}
$$

Albumin, globulin, and serum protein $\mathrm{N}$ were multiplied by 6.25 to give values as protein, while gelatin $\mathrm{N}$ values were multiplied by 5.7 to give gelatin values. As a check on the total nitrogen determinations in the serum, total protein determinations were also made by the falling drop method of Barbour and Hamilton (8). These usually agreed well with the sum of the serum protein plus gelatin concentrations, indicating that for the relatively small concentrations of gelatin, very little error was introduced by calculating the gelatin influence on the specific gravity as equal to that of the same weight of serum protein. Since it was found that the urine of these sub- jects never contained any protein precipitable by trichloroacetic acid, urinary gelatin $\mathrm{N}$ could be determined by subtracting the NPN from the total N without any appreciable error.

Creatinine determinations were made in plasma and urine by a photoelectric modification (9) of the Folin method. Plasma volume estimations were carried out by the photoelectric Evans Blue method in which a control and single 10-minute sample were taken, as suggested by Gregersen (10). The determinations were made just before the injection of gelatin and immediately after the end of the injection.

\section{RESULTS}

Plasma gelatin concentration. The data for 20 cases of heavy gelatin injections, 9 intermediate, and 13 light gelatin injections are given in Tables IA, IB, and IC respectively. The highest plasma gelatin concentration, achieved at the end of the injection, ranged between 0.59 to 1.17 grams per $100 \mathrm{ml}$. The averages for the three types were almost identical $(0.78,0.79$, and 0.78 gram per $100 \mathrm{ml}$. respectively). There was some indication that the levels were proportional to the speed of the injection; but this impression was not con-

\begin{tabular}{|c|c|c|c|c|c|c|}
\hline \multirow{2}{*}{ Lot no. } & \multirow{2}{*}{ Patient } & \multicolumn{5}{|c|}{ Hours after completion of injection } \\
\hline & & $\mathbf{0}$ & 2 & 4 & 6 & 24 \\
\hline $58-10$ & $\begin{array}{l}\text { A.A. } \\
\text { J.S. } \\
\text { C.T. } \\
\text { H.M. } \\
\text { G.B. } \\
\text { J.O. } \\
\text { H.H. } \\
\text { O.B. } \\
\text { F.B. } \\
\text { J.D. } \\
\text { A.W. } \\
\text { L.Y. } \\
\text { A.D. } \\
\text { A.E. }\end{array}$ & \begin{tabular}{|c|} 
grams per \\
$100 \mathrm{ml}$. \\
0.82 \\
0.83 \\
0.72 \\
0.91 \\
0.86 \\
0.77 \\
0.63 \\
0.75 \\
0.76 \\
0.74 \\
0.74 \\
0.88 \\
0.75 \\
0.69
\end{tabular} & \begin{tabular}{|c|} 
grams per \\
$100 \mathrm{ml}$ \\
0.74 \\
\\
0.60 \\
0.75 \\
\\
\\
0.50 \\
0.61 \\
0.61 \\
0.64 \\
0.68
\end{tabular} & $\begin{array}{c}\text { grams per } \\
100 \mathrm{ml} \text {. } \\
0.57 \\
\\
0.58 \\
0.72 \\
\\
\\
0.49 \\
0.48 \\
0.60 \\
0.59 \\
0.62\end{array}$ & $\begin{array}{c}\text { grams per } \\
100 \mathrm{ml} \text {. } \\
\\
0.51 \\
0.52 \\
\\
\\
0.47 \\
0.46 \\
0.53 \\
0.54 \\
0.53\end{array}$ & $\begin{array}{c}\text { grams per } \\
\text { 100 ml. } \\
0.29 \\
0.32 \\
0.33 \\
0.43 \\
0.41 \\
0.44 \\
0.24 \\
0.32 \\
0.31 \\
0.35 \\
0.40 \\
0.38 \\
0.27 \\
0.38\end{array}$ \\
\hline 83 & W.H. & 0.86 & 0.82 & 0.66 & 0.47 & 0.43 \\
\hline 93 & $\begin{array}{l}\text { R.R. } \\
\text { D.C. } \\
\text { C.W. } \\
\text { P.W. } \\
\text { J.R. }\end{array}$ & $\begin{array}{l}0.77 \\
0.93 \\
0.79 \\
0.68 \\
0.74\end{array}$ & $\begin{array}{l}0.74 \\
0.72 \\
0.64 \\
\\
0.72\end{array}$ & $\begin{array}{l}0.69 \\
0.71 \\
0.65 \\
0.55 \\
0.71\end{array}$ & $\begin{array}{l}0.62 \\
0.58 \\
0.58 \\
0.55\end{array}$ & $\begin{array}{l}0.40 \\
0.29 \\
0.41 \\
0.35 \\
0.29\end{array}$ \\
\hline \multicolumn{2}{|c|}{$\begin{array}{l}\text { Average and } \\
\text { standard devi- } \\
\text { ation }\end{array}$} & $\begin{array}{r}0.78 \\
\pm 0.07\end{array}$ & $\begin{array}{r}0.66 \\
\pm 0.08\end{array}$ & $\begin{array}{r}0.64 \\
\pm 0.08\end{array}$ & $\begin{array}{r}0.52 \\
\pm 0.05\end{array}$ & $\begin{array}{r}0.35 \\
\pm 0.06\end{array}$ \\
\hline
\end{tabular}

TABLE IA

Plasma gelatin concentration after intravenous injection of $1000 \mathrm{ml}$. of 5 per cent "heavy" gelatin 
TABLE IB

Plasma gelatin concentration after intravenous injection of $100 \mathrm{ml}$. of 5 per cent "intermediate" gelatin

\begin{tabular}{|c|c|c|c|c|c|c|}
\hline \multirow{2}{*}{ Lot no. } & \multirow{2}{*}{ Patient } & \multicolumn{5}{|c|}{ Hours after completion of injection } \\
\hline & & $\mathbf{0}$ & 2 & 4 & 6 & 24 \\
\hline $58-15$ & $\begin{array}{l}\text { O.B. } \\
\text { H.C. } \\
\text { S.S. } \\
\text { F.F. }\end{array}$ & $\begin{array}{c}\text { grams per } \\
100 \mathrm{ml} \text {. } \\
0.82 \\
0.75 \\
0.88 \\
0.92\end{array}$ & $\begin{array}{c}\text { grams per } \\
100 \mathrm{ml} . \\
0.67 \\
0.59 \\
0.67 \\
0.74\end{array}$ & $\begin{array}{c}\text { grams per } \\
100 \mathrm{ml} . \\
0.61 \\
0.59 \\
0.65 \\
0.65\end{array}$ & $\begin{array}{c}\text { grams per } \\
100 \mathrm{ml} \\
0.58 \\
0.53 \\
0.57 \\
0.62\end{array}$ & $\begin{array}{c}\text { grams per } \\
100 \mathrm{ml} \text {. } \\
0.11 \\
0.16 \\
0.35 \\
0.44\end{array}$ \\
\hline 101 & $\begin{array}{l}\text { J.M. } \\
\text { R.Y. } \\
\text { H.M. } \\
\text { F.B. } \\
\text { W.C. }\end{array}$ & $\begin{array}{l}0.95 \\
0.73 \\
0.64 \\
0.68 \\
0.74\end{array}$ & $\begin{array}{l}0.64 \\
0.49 \\
0.38 \\
0.43 \\
0.55\end{array}$ & $\begin{array}{l}0.59 \\
0.43 \\
0.35 \\
0.33 \\
0.46\end{array}$ & $\begin{array}{l}0.55 \\
0.33 \\
0.31 \\
0.29 \\
0.41\end{array}$ & $\begin{array}{l}0.12 \\
0.13\end{array}$ \\
\hline \multicolumn{2}{|c|}{$\begin{array}{l}\text { Average and } \\
\text { standard devi- } \\
\text { ation }\end{array}$} & $\begin{array}{r}0.79 \\
\pm 0.10\end{array}$ & $\begin{array}{r}0.57 \\
\pm 0.11\end{array}$ & $\begin{array}{r}0.52 \\
\pm 0.12\end{array}$ & $\begin{array}{r}0.47 \\
\pm 0.12\end{array}$ & $\begin{array}{r}0.22 \\
\pm 0.13\end{array}$ \\
\hline
\end{tabular}

TABLE IC

Plasma gelatin concentration after intravenous injection of $1000 \mathrm{ml}$. of 5 per cent "light" gelatin

\begin{tabular}{|c|c|c|c|c|c|c|}
\hline \multirow{2}{*}{ Lot no. } & \multirow{2}{*}{ Patient } & \multicolumn{5}{|c|}{ Hours after completion of injection } \\
\hline & & $\mathbf{0}$ & 2 & 4 & 6 & 24 \\
\hline 39 & $\begin{array}{l}\text { J.C. } \\
\text { C.U. } \\
\text { L.B. }\end{array}$ & $\begin{array}{c}\text { grams per } \\
100 \text { ml. } \\
0.59 \\
0.69 \\
0.78\end{array}$ & $\begin{array}{c}\text { grams per } \\
100 \text { ml. } \\
0.51 \\
0.51 \\
0.63\end{array}$ & $\begin{array}{c}\text { grams per } \\
100 \mathrm{ml} . \\
0.36 \\
0.41 \\
0.45\end{array}$ & $\begin{array}{c}\text { grams per } \\
100 \text { ml. } \\
0.36 \\
0.32 \\
0.45\end{array}$ & $\begin{array}{c}\text { grams per } \\
100 \mathrm{ml} \text {. } \\
0.34 \\
0.20 \\
0.42\end{array}$ \\
\hline 45 & $\begin{array}{l}\text { S.M. } \\
\text { C.P. }\end{array}$ & $\begin{array}{l}0.90 \\
0.84\end{array}$ & $\begin{array}{l}0.62 \\
0.60\end{array}$ & $\begin{array}{l}0.56 \\
0.51\end{array}$ & $\begin{array}{l}0.53 \\
0.47\end{array}$ & $\begin{array}{l}0.37 \\
0.35\end{array}$ \\
\hline 65 & $\begin{array}{l}\text { L.P. } \\
\text { L.M. } \\
\text { Lu.M. } \\
\text { J.W. }\end{array}$ & $\begin{array}{l}1.17 \\
0.77 \\
0.68 \\
0.78\end{array}$ & $\begin{array}{l}0.67 \\
0.55 \\
0.43\end{array}$ & $\begin{array}{l}0.61 \\
0.51 \\
0.42\end{array}$ & $\begin{array}{l}0.51 \\
0.46 \\
0.27\end{array}$ & $\begin{array}{l}0.40 \\
0.33 \\
0.14 \\
0.48\end{array}$ \\
\hline 80 & $\begin{array}{l}\text { A.T. } \\
\text { H.R. } \\
\text { J.S. } \\
\text { B.C. }\end{array}$ & $\begin{array}{l}0.67 \\
0.87 \\
0.88 \\
0.71\end{array}$ & $\begin{array}{l}0.52 \\
0.55 \\
0.52 \\
0.54\end{array}$ & $\begin{array}{l}0.45 \\
0.52 \\
0.43 \\
0.52\end{array}$ & $\begin{array}{l}0.42 \\
0.46 \\
0.27 \\
0.39\end{array}$ & $\begin{array}{l}0.34 \\
0.40 \\
0.24 \\
0.08\end{array}$ \\
\hline \multicolumn{2}{|c|}{$\begin{array}{l}\text { Average and } \\
\text { standard devi- } \\
\text { ation }\end{array}$} & $\begin{array}{r}0.79 \\
\pm 0.14\end{array}$ & $\begin{array}{r}0.55 \\
\pm 0.06\end{array}$ & $\begin{array}{r}0.48 \\
\pm 0.07\end{array}$ & $\begin{array}{c}0.41 \\
\pm 0.095\end{array}$ & $\begin{array}{r}0.32 \\
\pm 0.11\end{array}$ \\
\hline \multicolumn{2}{|c|}{$t$ (heavy-light) } & 0.3 & 4.5 & 6.0 & 4.3 & 1.0 \\
\hline
\end{tabular}

firmed, for no attempt was made to vary the speed of injection.

In a few cases plasma gelatin levels were determined during the administration of the gelatin. These values were always lower than those obtained at the end of the injection. Similarly, in the preliminary-series of experiments in which
$2000 \mathrm{ml}$. were injected, the plasma gelatin concentration reached at the end of $1000 \mathrm{ml}$. was always lower than that obtained at the end of $2000 \mathrm{ml}$. Thus it was certain that the rate of removal of gelatin from the blood stream was always slower than that of the ingress, if the injection was made at the common clinical speed.

The plasma gelatin concentrations dropped progressively in 24 hours to $0.35,0.22$, and $0.32 \mathrm{mgm}$. per $100 \mathrm{ml}$. respectively for the heavy, intermediate, and light gelatins. There were still appreciable concentrations of gelatin in the plasma at 48 and 72 hours, which finding was confirmed by the demonstrable excretion of gelatin on the third and fourth days. Though a comparison of the levels at the end of the injection and at 24 hours did not reveal any appreciable differences between the heavy and light gelatin (the $t$ value of statistically significant difference ${ }^{4}$ being 0.3 for 0 hour and 1.0 for 24 hours), such a comparison made at 2,4 , and 6 hours showed that the rate of fall in plasma gelatin concentration during this period was far greater for the light gelatin than for the heavy variety. This difference is apparent in the curves of plasma gelatin concentration shown in Figure 1. That the difference is not fortuitous is indicated by the $t$ values of 4.5 at 2 hours, 6.0 at 4 hours, and 4.3 at 6 hours. The heavy gelatin thus tended to maintain an effective concentration longer than did the light gelatin. A possible explanation for this phenomenon will become recognizable when the excretion data are analyzed. The plasma gelatin concentrations at 2, 4, and 6 hours for the intermediate types appeared to fall in between those of the other two types, but the differences were less significant chiefly because

4 The $t$ value of statistically significant difference between the average of two sets of experimental values was determined according to the method of Snedecor (11) as follows :

$$
t=\frac{a_{1}-a_{2}}{\sqrt{\frac{\sigma_{1}^{2}}{n_{1}}+\frac{\sigma_{2}^{2}}{n_{2}}}}
$$

where $a_{1}, \sigma_{1}$, and $n_{1}$ are respectively the mean, the standard deviation, and the number of experiments in the one set of experiments, and $a_{2}, \sigma_{2}$, and $n_{2}$ are those in the second group of experiments. A value of 2.5 or more for $t$ indicates that the difference of the means is at least 4 times as great as the probable error of the difference of the means and is therefore probably a significant difference. 


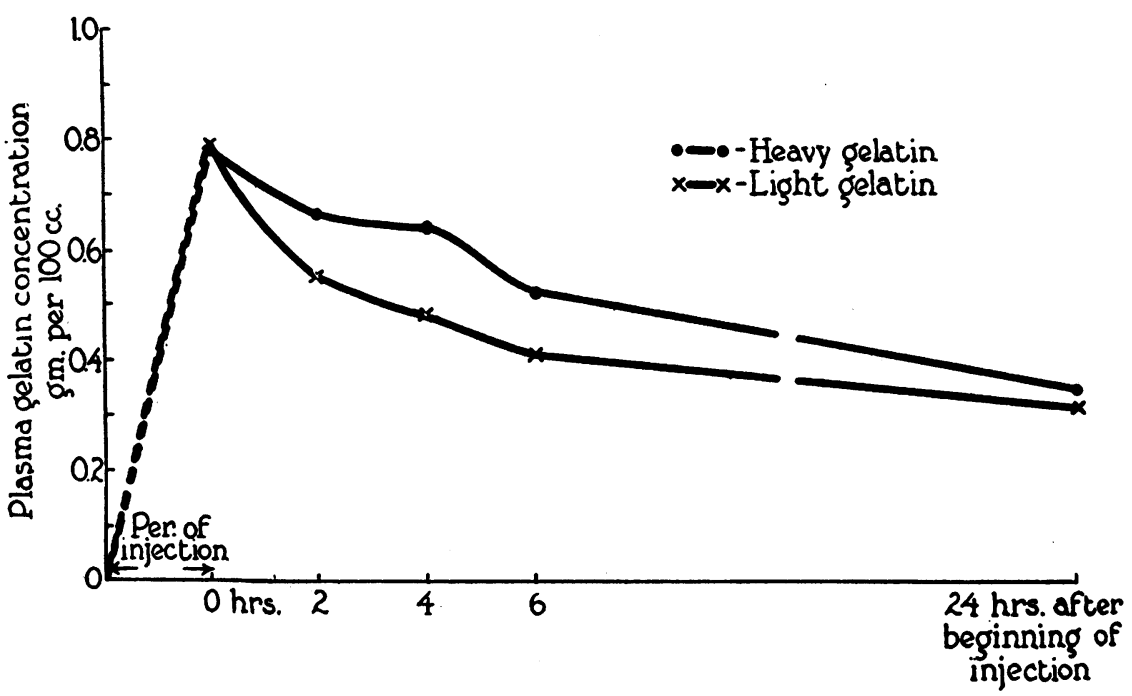

Fig. 1. Comparison Between Average Plasma Gelatin Concentrations After Injection of Heavy Gelatin and Those After Light Gelatin

the variations were greater for the intermediate type.

Urinary excretion of gelatin. The data for the excretion of gelatin in the urine for 14 heavy gelatin injections, 9 intermediate and 12 light gelatin injections are shown in Table IIA, IIB, and IIC respectively. It is obvious that the rate of excretion shows a marked variability even in injections of the same lot of gelatin. However a pattern of excretion is discernible. In all cases there was a considerable excretion of gelatin by the time of the end of the injection. At 6 hours after the com- pletion of the injection an average of 22.72 grams of light gelatin had been excreted. The heavy gelatin excretion in this period was significantly less, averaging 14.68 grams. The intermediate gelatin excretion was 21.72 grams. There was much less variation in the individual excretion of the heavy gelatin at 6 hours than in those of light gelatin, the standard deviation being 2.50 while that for the light gelatin was 4.22. These findings were consistent with the differences in plasma levels by the end of 6 hours. That the difference between the excretion of heavy and light gelatin

TABLE IIA

Urinary excretion of "heavy" gelatin after intravenous injection of $1000 \mathrm{ml}$. of 5 per cent solution

\begin{tabular}{|c|c|c|c|c|c|c|c|c|c|c|c|c|c|c|c|c|}
\hline & \multicolumn{8}{|c|}{ Lot no. 58-10 } & \multicolumn{4}{|c|}{ Lot no. 93} & \multicolumn{2}{|c|}{ Lot no. 83} & \multirow{2}{*}{$\begin{array}{c}\text { Aver- } \\
\text { age }\end{array}$} & \multirow{2}{*}{$\begin{array}{c}\text { Standard } \\
\text { devia- } \\
\text { tion }\end{array}$} \\
\hline & c.T. & H.M. & A.H. & F.B. & A.A. & J.D. & A.w. & O.B. & D.C. & R.R. & c.w. & P.W. & J.R. & W.H. & & \\
\hline $\begin{array}{l}\text { At end of in- } \\
\text { jection } \\
2 \text { hrs. after } \\
4 \text { hrs. after } \\
6 \text { hrs. after }\end{array}$ & $\begin{array}{r}\text { grams } \\
6.36 \\
\\
4.39 \\
1.81 \\
3.74\end{array}$ & \begin{tabular}{r|} 
grams \\
7.85 \\
\\
3.78 \\
4.63 \\
2.69
\end{tabular} & \begin{tabular}{|r|} 
grams \\
1.38 \\
\\
2.87 \\
4.91 \\
1.36
\end{tabular} & \begin{tabular}{|r|} 
grams \\
1.85 \\
\\
4.75 \\
2.98 \\
3.17
\end{tabular} & \begin{tabular}{|c|} 
grams \\
2.41 \\
\\
7.92 \\
4.63 \\
2.41 \\
\end{tabular} & \begin{tabular}{|r} 
grams \\
7.15 \\
\\
1.23 \\
1.60 \\
4.69
\end{tabular} & $\begin{array}{r}\text { grams } \\
6.47 \\
\\
5.21 \\
2.90 \\
1.25\end{array}$ & \begin{tabular}{r|} 
grams \\
7.29 \\
\\
3.76 \\
1.72 \\
1.07 \\
\end{tabular} & \begin{tabular}{|c|} 
grams \\
6.20 \\
\\
5.16 \\
2.54 \\
0.98
\end{tabular} & \begin{tabular}{|r} 
grams \\
14.63 \\
\\
5.52 \\
1.81
\end{tabular} & \begin{tabular}{|c} 
grams \\
17.45 \\
\\
4.13 \\
2.20 \\
1.15
\end{tabular} & $\begin{array}{r}\text { grams } \\
8.87\end{array}$ & $\begin{array}{r}\text { grams } \\
6.89 \\
\\
2.27 \\
2.52\end{array}$ & $\begin{array}{r}\text { grams } \\
5.56 \\
3.19 \\
3.34 \\
3.53\end{array}$ & grams & grams \\
\hline Total to $6 \mathrm{hrs}$. & 16.30 & 18.95 & 10.52 & 12.75 & 17.37 & 14.67 & 15.83 & 13.84 & 14.98 & & & 10.67 & & 15.62 & 14.68 & \pm 2.50 \\
\hline $\begin{array}{l}24 \text { hrs. } \\
48 \text { hrs. } \\
72 \text { hrs. }\end{array}$ & & $\begin{array}{l}7.81 \\
9.44 \\
6.03\end{array}$ & $\begin{array}{r}15.55 \\
7.76\end{array}$ & $\begin{array}{r}7.93 \\
18.15 \\
2.96\end{array}$ & $\begin{array}{l}8.36 \\
4.53 \\
4.33\end{array}$ & & $\begin{array}{r}8.89 \\
16.52 \\
3.21\end{array}$ & $\begin{array}{r}6.51 \\
6.64 \\
5.30\end{array}$ & $\begin{array}{l}5.23 \\
3.37 \\
8.62\end{array}$ & $\begin{array}{l}5.92 \\
5.83 \\
1.29\end{array}$ & 1.78 & 14.44 & $\begin{array}{r}23.38 \\
4.00 \\
0.39\end{array}$ & $\begin{array}{r}6.37 \\
14.35\end{array}$ & & \\
\hline $\begin{array}{l}\text { Total to } 72 \\
\text { hours }\end{array}$ & & 42.23 & & 41.79 & 34.59 & & 44.45 & 42.30 & 32.20 & 34.90 & & & 39.47 & & 39.00 & \pm 4.21 \\
\hline
\end{tabular}

$t$ (Average "heavy" gelatin excretion to 6 hours compared with average "light" gelatin excretion, to 6 hours) 5.6. $t$ (Average "heavy" gelatin excretion to 72 hours compared with average "light" gelatin excretion to 72 hours) 0.7 . 
TABLE IIB

Urinary excretion of "intermediate" gelatin after intravenous injection of $1000 \mathrm{ml}$. of 5 per cent solution

\begin{tabular}{|c|c|c|c|c|c|c|c|c|c|c|c|}
\hline & \multicolumn{4}{|c|}{ Lot no. 58-15 } & \multicolumn{5}{|c|}{ Lot no. 101} & \multirow{2}{*}{ Average } & \multirow{2}{*}{$\begin{array}{c}\text { Standard } \\
\text { devia- } \\
\text { tion }\end{array}$} \\
\hline & U.B. & H.C. & s.s. & F.F. & J.M. & R.Y. & M.H. & F.B. & w.c. & & \\
\hline $\begin{array}{l}\text { At end of injection } \\
2 \text { hrs. after } \\
4 \text { hrs. after } \\
6 \text { hrs. after }\end{array}$ & $\begin{array}{r}\text { grams } \\
22.06 \\
2.31 \\
2.08 \\
1.63\end{array}$ & $\begin{array}{r}\text { grams } \\
10.18 \\
5.56 \\
2.41 \\
1.31\end{array}$ & $\begin{array}{r}\text { grams } \\
7.17 \\
4.73 \\
4.77 \\
\cdot 1.17\end{array}$ & $\begin{array}{r}\text { grams } \\
4.63 \\
5.75 \\
7.33 \\
2.95\end{array}$ & $\begin{array}{r}\text { grams } \\
14.96 \\
8.13 \\
\\
5.92\end{array}$ & $\begin{array}{r}\text { grams } \\
7.99 \\
9.51 \\
2.56 \\
1.61\end{array}$ & $\begin{array}{c}\text { grams } \\
10.29 \\
\\
5.69 \\
1.85\end{array}$ & $\begin{array}{r}\text { grams } \\
5.60 \\
8.81 \\
2.45 \\
1.33\end{array}$ & $\begin{array}{r}\text { grams } \\
8.18 \\
10.56 \\
3.41 \\
0.58\end{array}$ & grams & grams \\
\hline Total to $6 \mathrm{hrs}$. & 28.08 & 19.46 & 17.84 & 20.66 & 29.01 & 21.67 & 17.83 & 18.19 & 22.73 & 21.72 & \pm 4.00 \\
\hline $\begin{array}{l}24 \text { hrs. } \\
48 \text { hrs. } \\
72 \text { hrs. }\end{array}$ & $\begin{array}{l}2.82 \\
5.67 \\
5.80\end{array}$ & $\begin{array}{l}3.24 \\
1.88 \\
7.55\end{array}$ & $\begin{array}{r}4.06 \\
10.94 \\
4.91\end{array}$ & $\begin{array}{l}3.75 \\
8.29 \\
2.79\end{array}$ & 6.72 & 6.16 & 7.98 & 8.09 & 5.70 & & \\
\hline Total to $72 \mathrm{hrs}$. & 42.37 & 32.13 & 37.75 & 35.49 & & & & & & 36.69 & \\
\hline 96 hrs. & 1.15 & 3.94 & 8.19 & 0.54 & & & & & & & \\
\hline
\end{tabular}

TABLE IIC

Urinary excretion of "light" gelatin after intravenous injection of $1000 \mathrm{ml}$. of 5 per cent solution

\begin{tabular}{|c|c|c|c|c|c|c|c|c|c|c|c|c|c|c|}
\hline & \multicolumn{3}{|c|}{ Lot no. 39} & \multicolumn{3}{|c|}{ Lot no. 65} & \multicolumn{3}{|c|}{ Lot no. 45} & \multicolumn{3}{|c|}{ Lot no. 80} & \multirow{2}{*}{$\begin{array}{c}\text { Aver- } \\
\text { age }\end{array}$} & \multirow{2}{*}{$\begin{array}{c}\text { Standard } \\
\text { devia- } \\
\text { tion }\end{array}$} \\
\hline & J.C. & C.U. & L.B. & L.P. & L.M. & LU.M. & S.M. & C.P. & A.F. & H.R. & J.S. & A.D. & & \\
\hline $\begin{array}{l}\text { At end of injection } \\
2 \text { hrs. after } \\
4 \text { hrs. after } \\
6 \text { hrs. after }\end{array}$ & \begin{tabular}{|r|} 
grams \\
18.24 \\
7.01 \\
2.53 \\
3.58
\end{tabular} & $\begin{array}{r}\text { grams } \\
12.97 \\
8.70 \\
3.41 \\
1.51\end{array}$ & \begin{tabular}{r|} 
grams \\
12.19 \\
10.06 \\
2.80 \\
1.43
\end{tabular} & $\begin{array}{r}\text { grams } \\
7.70 \\
9.32 \\
4.01 \\
1.90\end{array}$ & \begin{tabular}{|r|} 
grams \\
5.65 \\
3.04 \\
2.14 \\
6.41
\end{tabular} & $\begin{array}{r}\text { grams } \\
12.14 \\
7.34 \\
4.39 \\
1.20\end{array}$ & \begin{tabular}{|r|} 
grams \\
14.50 \\
6.53 \\
3.59 \\
1.62 \\
\end{tabular} & $\begin{array}{r}\text { grams } \\
8.84 \\
8.90 \\
2.66 \\
1.01\end{array}$ & \begin{tabular}{|r|} 
grams \\
9.70 \\
4.22 \\
1.11 \\
3.46
\end{tabular} & \begin{tabular}{|r|} 
grams \\
12.41 \\
3.02 \\
2.48 \\
0.73
\end{tabular} & $\begin{array}{r}\text { grams } \\
9.23 \\
4.65 \\
3.10 \\
1.59\end{array}$ & $\begin{array}{r}\text { grams } \\
9.25 \\
5.58 \\
1.71 \\
3.10\end{array}$ & grams & grams \\
\hline Total to $6 \mathrm{hrs}$. & 31.36 & 26.59 & 26.48 & 22.93 & 17.24 & 25.07 & 26.21 & 21.41 & 18.49 & 18.64 & 18.57 & 19.64 & $22.72 *$ & \pm 4.22 \\
\hline $\begin{array}{l}24 \text { hrs. } \\
48 \text { hrs. } \\
72 \text { hrs. }\end{array}$ & $\begin{array}{l}8.72 \\
1.73 \\
0.73\end{array}$ & $\begin{array}{l}4.59 \\
3.24 \\
2.41\end{array}$ & $\begin{array}{l}5.79 \\
2.17\end{array}$ & 9.10 & $\begin{array}{r}6.30 \\
4.61 \\
15.81 \\
\end{array}$ & $\begin{array}{l}2.33 \\
4.02\end{array}$ & $\begin{array}{l}6.74 \\
3.23 \\
1.63\end{array}$ & $\begin{array}{l}6.96 \\
5.74\end{array}$ & $\begin{array}{l}7.02 \\
2.07 \\
8.86\end{array}$ & $\begin{array}{r}15.20 \\
2.58 \\
1.04\end{array}$ & $\begin{array}{r}23.37 \\
1.54 \\
0.08\end{array}$ & $\begin{array}{r}17.60 \\
2.79 \\
2.10\end{array}$ & & \\
\hline Total to $72 \mathrm{hrs}$. & 42.54 & 36.83 & & & 43.96 & & 38.84 & & 36.44 & 37.46 & 43.56 & 42.13 & 40.22 & \pm 2.93 \\
\hline
\end{tabular}

* If lot 80 is omitted, average excretion to 6 hours is 24.66 .

was significant was shown by the $t$ value of 5.6. By the end of 72 hours, the differences in excretion had largely disappeared. After the 6-hour period, the heavy gelatin began to be excreted more rapidly than the lighter gelatin, so that at 72 hours, an average of 39.00 grams was accounted for in the urine, while for the light gelatin 40.22 grams were excreted. The $t$ value for these differences was only 0.7 which means that the difference was probably statistically insignificant.

For the 9 cases of injection of intermediate gelatin, there were not enough data at 72 hours to allow statistical evaluation, but here, too, it appeared that the final total excretion was of the same order as that for the heavy and light gelatin.

In a few cases determinations of gelatin excre- tion were made for the fourth day. An appreciable quantity of gelatin was invariably recovered, occasionally as much as $\mathbf{5}$ grams. Traces of gelatin were found in the urine on the fifth day, but the values often lay within the probable error of the determination. Since some 80 per cent of the injected gelatin could be accounted for in the urine in 72 hours, and since gelatin was still being excreted on the fourth, and presumably on the fifth day, it was probable that little or no gelatin was degraded to products smaller than those precipitated by alcohol. The lack of any significant rise in serum NPN and urea $\mathrm{N}$ during or after injection was in agreement with this interpretation, which is contrary to the conclusion arrived at by Brunschwig (12). 
In Table IIC, it will be noticed that the excretion of Lot 80 at 6 hours was slower than that of the other light gelatin lots, and that correspondingly the excretion of Lot 80 after 6 hours up to 72 hours was greater than that of the other lots. All 4 of these subjects treated with this lot of gelatin showed a moderate pyrogenic reaction at the end of the excretion. The reactions were not severe, and they occurred so near the end of the injection, that the experiments were carried through to completion. The excretions of gelatin in these cases for the period up to the end of the injection were of the same order as that for the other light lots. But for the next 6 hours there was a markedly diminished gelatin output. That this decrease was due to diminished renal function was indicated by the fact that the creatinine clearances (Table IIIC) were appreciably lower than normal. In three of the four cases, this diminished excretion was compensated for by an unusually large excretion during the remainder of the first day. In the fourth case, the excretion was delayed to the third day (and fourth day, which is not shown in the Table). If Lot 80 is omitted entirely from the calculation of the excretion of light gelatin at 6 hours, the average ex- cretion at 6 hours is increased from 22.72 to 24.66 grams, and the difference between this excretion and the average for heavy gelatin at 6 hours becomes even greater.

Gelatin and creatinine clearances. Tables IIIA, IIIB, and IIIC show the endogenous creatinine and gelatin clearances and gelatin-creatinine ratios for 12 heavy, 9 intermediate, and 11 light gelatin experiments. Though all subjects chosen were thought to have normal renal function, a few showed abnormally low and an occasional one abnormally high creatinine clearances. These abnormalities could for the most part be accounted for by the fact that catheterization was not resorted to, and that volume errors occurred, in one direction in the first two hours and in the reverse direction in the second. Some of the abnormality might have been due to the effect of gelatin injection. On the one hand, the increased plasma volume produced by the gelatin injection should have produced a greater renal flow and a greater glomerular filtration. On the other hand, the excretion of a highly concentrated and viscous gelatin-containing urine might temporarily block a number of tubules and thus temporarily reduce renal function. It is significant that the large ma-

TABLE IIIA

Gelatin and creatinine clearances for injection of "heavy" gelatin

\begin{tabular}{|c|c|c|c|c|c|c|c|c|c|c|}
\hline \multirow[b]{2}{*}{ Lot no. } & \multirow[b]{2}{*}{ Patient } & \multicolumn{3}{|c|}{0 to $2 \mathrm{hrs}$. after injection } & \multicolumn{3}{|c|}{2 to $4 \mathrm{hrs}$. after injection } & \multicolumn{3}{|c|}{4 to $6 \mathrm{hrs}$. after injection } \\
\hline & & $\begin{array}{c}\text { Gelatin } \\
\text { clearance } \\
\text { G }\end{array}$ & $\begin{array}{l}\text { Creatinine } \\
\text { clearance } \\
\text { C }\end{array}$ & $\begin{array}{c}\mathrm{G} / \mathrm{C} \\
(\times 100)\end{array}$ & $\begin{array}{c}\text { Gelatin } \\
\text { clearance } \\
\text { G }\end{array}$ & $\begin{array}{c}\text { Creatinine } \\
\text { clearance } \\
\text { C }\end{array}$ & $\begin{array}{c}\mathrm{G} / \mathrm{C} \\
(\times 100)\end{array}$ & $\begin{array}{c}\text { Gelatin } \\
\text { clearance } \\
\text { G }\end{array}$ & $\begin{array}{l}\text { Creatinine } \\
\text { clearance } \\
\text { C }\end{array}$ & $\begin{array}{l}\text { G/C } \\
(\times 100)\end{array}$ \\
\hline $58-10$ & $\begin{array}{l}\text { A.H. } \\
\text { J.D. } \\
\text { A.W. } \\
\text { H.M. } \\
\text { C.T. } \\
\text { F.B. } \\
\text { O.B. }\end{array}$ & $\begin{array}{c}\text { ml. per min. } \\
4.33 \\
1.67 \\
7.68 \\
4.03 \\
6.63 \\
6.03 \\
2.09\end{array}$ & $\begin{array}{c}\text { ml. per min. } \\
86.4 \\
43.2 \\
136 \\
146 \\
171 \\
93.5 \\
61.5\end{array}$ & $\begin{array}{l}5.01 \\
3.87 \\
5.65 \\
2.74 \\
3.88 \\
6.45 \\
3.40\end{array}$ & \begin{tabular}{|c|} 
ml. per min. \\
8.26 \\
2.46 \\
3.85 \\
6.93 \\
3.17 \\
5.09 \\
2.66
\end{tabular} & $\begin{array}{c}\text { ml. per min. } \\
170 \\
83.6 \\
135 \\
135 \\
177 \\
112.5 \\
112\end{array}$ & $\begin{array}{l}4.85 \\
2.94 \\
2.85 \\
5.14 \\
1.79 \\
4.52 \\
2.37\end{array}$ & \begin{tabular}{|c|} 
ml. per min. \\
3.59 \\
5.08 \\
1.50 \\
4.45 \\
6.40 \\
4.59 \\
1.95
\end{tabular} & $\begin{array}{c}\text { ml. per min. } \\
86.5 \\
133.8 \\
97.8 \\
151 \\
162 \\
207 \\
111\end{array}$ & $\begin{array}{l}4.15 \\
3.80 \\
1.53 \\
2.94 \\
3.95 \\
2.21 \\
1.76\end{array}$ \\
\hline 93 & $\begin{array}{l}\text { C.W. } \\
\text { R.R. } \\
\text { J.R. } \\
\text { D.C. } \\
\text { P.W. }\end{array}$ & $\begin{array}{l}4.78 \\
6.96 \\
2.59 \\
6.58 \\
0.636^{*}\end{array}$ & $\begin{array}{c}134 \\
182 \\
133 \\
122 \\
36^{*}\end{array}$ & $\begin{array}{l}3.57 \\
3.42 \\
1.95 \\
5.40 \\
1.77^{*}\end{array}$ & $\begin{array}{l}3.25 \\
2.07 \\
2.94 \\
3.11 \\
0.636 *\end{array}$ & $\begin{array}{c}112 \\
137 \\
126 \\
118 \\
36^{*}\end{array}$ & $\begin{array}{l}2.90 \\
1.51 \\
2.33 \\
2.64 \\
1.77^{*}\end{array}$ & $\begin{array}{l}1.45 \\
\\
1.89 \\
1.63\end{array}$ & $\begin{array}{l}138 \\
93.3 \\
123\end{array}$ & $\begin{array}{l}1.05 \\
2.03 \\
1.33\end{array}$ \\
\hline 83 & W.H. & 3.39 & 86.5 & 3.92 & 3.72 & 134 & 2.78 & 5.42 & 92.3 & 5.87 \\
\hline \multicolumn{2}{|c|}{$\begin{array}{l}\text { Average and } \\
\text { standard devi- } \\
\text { ation }\end{array}$} & & & $\begin{array}{r}3.93 \\
\pm 1.45\end{array}$ & & & $\begin{array}{r}2.95 \\
\pm 1.13\end{array}$ & & & $\begin{array}{r}2.78 \\
\pm 1.25\end{array}$ \\
\hline
\end{tabular}

$t$ (Mean G/C for 0 to 2 hours compared with mean G/C for 2 to 4 hours) 1.9.

$t$ (Mean G/C for 2 to 4 hours compared with mean $G / C$ for 4 to 6 hours) 0.4 .

* Single clearance test over a period of 4 hours. 
FATE OF INTRAVENOUSLY INJECTED GELATIN IN HUMANS

TABLE IIIB

Gelatin and creatinine clearances for injection of "intermediate" gelatin

\begin{tabular}{|c|c|c|c|c|c|c|c|c|c|c|}
\hline \multirow[b]{2}{*}{ Lot no. } & \multirow[b]{2}{*}{ Patient } & \multicolumn{3}{|c|}{0 to $2 \mathrm{hrs}$. after injection } & \multicolumn{3}{|c|}{2 to $4 \mathrm{hrs}$. after injection } & \multicolumn{3}{|c|}{4 to $6 \mathrm{hrs}$. after injection } \\
\hline & & $\begin{array}{c}\text { Gelatin } \\
\text { clearance } \\
\mathbf{G}\end{array}$ & $\begin{array}{c}\text { Creatinine } \\
\text { clearance } \\
\text { C }\end{array}$ & $\begin{array}{l}\text { G/C } \\
(\times 100)\end{array}$ & $\begin{array}{c}\text { Gelatin } \\
\text { clearance } \\
\mathbf{G}\end{array}$ & $\underset{\text { Creatinine }}{\text { Clearance }}$ & $\begin{array}{l}\mathrm{G} / \mathrm{C} \\
(\mathrm{X} \mathbf{1 0 0})\end{array}$ & $\begin{array}{c}\text { Gelatin } \\
\text { clearance } \\
\text { G }\end{array}$ & $\begin{array}{l}\text { Creatinine } \\
\text { clearance } \\
\text { C }\end{array}$ & $\begin{array}{c}\mathrm{G} / \mathrm{C} \\
(\mathrm{X} 100)\end{array}$ \\
\hline $58-15$ & $\begin{array}{l}\text { U.B. } \\
\text { S.S. } \\
\text { H.C. } \\
\text { F.F. }\end{array}$ & $\begin{array}{c}\text { ml. per min. } \\
2.78 \\
5.59 \\
7.34 \\
5.23\end{array}$ & $\begin{array}{c}\text { ml. per min. } \\
126 \\
56.2 \\
118 \\
269\end{array}$ & $\begin{array}{l}2.21 \\
8.09 \\
6.23 \\
1.94\end{array}$ & $\begin{array}{c}\text { ml. per min. } \\
3.16 \\
6.83 \\
3.40 \\
8.31\end{array}$ & $\begin{array}{c}\text { ml. per min. } \\
113 \\
65.4 \\
159 \\
227\end{array}$ & $\begin{array}{r}2.79 \\
10.44 \\
2.14 \\
3.66\end{array}$ & $\begin{array}{c}\text { ml. per min. } \\
2.88 \\
2.18 \\
1.62 \\
4.04\end{array}$ & $\begin{array}{c}\text { ml. per min. } \\
116 \\
55.5 \\
119 \\
99\end{array}$ & $\begin{array}{l}2.48 \\
3.93 \\
1.36 \\
4.08\end{array}$ \\
\hline 101 & $\begin{array}{l}\text { J.M. } \\
\text { W.C. } \\
\text { F.B. } \\
\text { H.M. } \\
\text { R.Y. }\end{array}$ & $\begin{array}{c}8.18 \\
14.4 \\
14.8 \\
4.88^{*} \\
12.48\end{array}$ & $\begin{array}{l}117 \\
125 \\
151.5 \\
114^{*} \\
151\end{array}$ & $\begin{array}{c}7.02 \\
11.50 \\
9.78 \\
4.28^{*} \\
8.24\end{array}$ & $\begin{array}{l}4.52^{*} \\
6.74 \\
6.32 \\
4.88^{*} \\
4.64\end{array}$ & $\begin{array}{l}124^{*} \\
111 \\
180 \\
114^{*} \\
105\end{array}$ & $\begin{array}{l}3.65^{*} \\
6.09 \\
3.51 \\
4.28^{*} \\
4.41\end{array}$ & $\begin{array}{l}4.52^{*} \\
1.64 \\
4.18 \\
5.31 \\
3.86\end{array}$ & $\begin{array}{c}124^{*} \\
88.5 \\
196 \\
130 \\
111\end{array}$ & $\begin{array}{l}3.65^{*} \\
1.85 \\
2.13 \\
4.09 \\
3.48\end{array}$ \\
\hline
\end{tabular}

$t$ (Mean G/C for 0 to 2 hours compared with mean G/C for 2 to 4 hours) 1.6. $t$ (Mean $G / C$ for 2 to 4 hours compared with mean $G / C$ for 4 to 6 hours) 1.8 .

* Single clearance test over a period of 4 hours.

TABLE IIIC

Gelatin and creatinine clearances for injections of "light" gelatin

\begin{tabular}{|c|c|c|c|c|c|c|c|c|c|c|}
\hline \multirow[b]{2}{*}{ Lot no. } & \multirow[b]{2}{*}{ Patient } & \multicolumn{3}{|c|}{0 to $2 \mathrm{hrs}$. after injection } & \multicolumn{3}{|c|}{2 to $4 \mathrm{hrs}$. after injection } & \multicolumn{3}{|c|}{4 to $6 \mathrm{hrs}$. after injection } \\
\hline & & 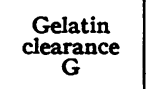 & $\begin{array}{l}\text { Creatinine } \\
\text { clearance } \\
\text { C }\end{array}$ & $\begin{array}{c}\mathrm{G} / \mathrm{C} \\
(\times 100)\end{array}$ & $\begin{array}{c}\text { Gelatin } \\
\text { clearance } \\
\mathbf{G}\end{array}$ & $\begin{array}{c}\text { Creatinine } \\
\text { clearance } \\
\text { C }\end{array}$ & $\begin{array}{c}\mathrm{G} / \mathrm{C} \\
(\times 100)\end{array}$ & $\begin{array}{c}\text { Gelatin } \\
\text { clearance } \\
\text { G }\end{array}$ & $\begin{array}{c}\text { Creatinine } \\
\text { clearance } \\
\text { C }\end{array}$ & $\begin{array}{l}\text { G/C } \\
(\times 100)\end{array}$ \\
\hline 65 & $\begin{array}{l}\text { L.M. } \\
\text { L.P. } \\
\text { Lu.M. }\end{array}$ & \begin{tabular}{|c|} 
ml. per min. \\
4.85 \\
12.72 \\
12.77
\end{tabular} & $\begin{array}{c}\text { ml. per min. } \\
57.1 \\
91.7 \\
91.3\end{array}$ & $\begin{array}{r}8.50 \\
13.88 \\
13.98\end{array}$ & $\begin{array}{c}\text { ml. per min. } \\
3.86 \\
7.02 \\
10.12\end{array}$ & $\begin{array}{c}\text { ml. per min. } \\
63.3 \\
135.5 \\
105.1\end{array}$ & $\begin{array}{r}6.10 \\
5.18 \\
.9 .63\end{array}$ & $\begin{array}{c}\text { ml. per min. } \\
6.75 \\
2.84 \\
3.17 \\
\end{array}$ & $\begin{array}{c}\text { ml. per min. } \\
144 \\
97.9 \\
68.3\end{array}$ & $\begin{array}{l}4.69 \\
2.90 \\
4.64\end{array}$ \\
\hline 39 & $\begin{array}{l}\text { C.U. } \\
\text { L.B. } \\
\text { J.C. }\end{array}$ & $\begin{array}{c}14.4 \\
13.3 \\
9.18\end{array}$ & $\begin{array}{l}161 \\
147 \\
134\end{array}$ & $\begin{array}{l}8.95 \\
9.05 \\
6.85\end{array}$ & $\begin{array}{l}6.22 \\
5.02 \\
5.75\end{array}$ & $\begin{array}{l}110 \\
131 \\
192\end{array}$ & $\begin{array}{l}5.66 \\
3.83 \\
3.00 \\
\end{array}$ & $\begin{array}{l}3.11 \\
2.97 \\
8.23\end{array}$ & $\begin{array}{r}89 \\
115 \\
154\end{array}$ & $\begin{array}{l}3.50 \\
2.58 \\
5.34\end{array}$ \\
\hline 45 & $\begin{array}{l}\text { C.P. } \\
\text { S.M. }\end{array}$ & $\begin{array}{r}11.78 \\
7.23\end{array}$ & $\begin{array}{c}102 \\
89.7\end{array}$ & $\begin{array}{r}11.52 \\
8.06\end{array}$ & $\begin{array}{l}4.16 \\
6.23\end{array}$ & $\begin{array}{c}126 \\
92.5\end{array}$ & $\begin{array}{l}3.30 \\
6.73\end{array}$ & $\begin{array}{l}1.80 \\
2.67\end{array}$ & $\begin{array}{c}116 \\
70.1\end{array}$ & $\begin{array}{l}1.55 \\
3.81\end{array}$ \\
\hline 80 & $\begin{array}{l}\text { H.R. } \\
\text { J.S. } \\
\text { A.D. }\end{array}$ & $\begin{array}{l}3.50 \\
6.00 \\
7.47\end{array}$ & $\begin{array}{l}33.0 \\
67.2 \\
96.5\end{array}$ & $\begin{array}{r}10.61 \\
8.93 \\
7.74\end{array}$ & $\begin{array}{l}3.89 \\
4.82 \\
3.01\end{array}$ & $\begin{array}{l}39.8 \\
86.4 \\
93.5\end{array}$ & $\begin{array}{l}9.77 \\
5.58 \\
3.22\end{array}$ & $\begin{array}{l}1.75 \\
5.06 \\
5.51\end{array}$ & $\begin{array}{l}45.3 \\
65.3 \\
97.5\end{array}$ & $\begin{array}{l}3.86 \\
4.75 \\
5.65\end{array}$ \\
\hline \multicolumn{2}{|c|}{$\begin{array}{l}\text { Average and } \\
\text { standard devi- } \\
\text { ation }\end{array}$} & & & $\begin{array}{r}9.82 \\
\pm 2.29\end{array}$ & & & $\begin{array}{r}5.64 \\
\pm 2.26\end{array}$ & & & $\begin{array}{r}3.93 \\
\pm 1.18\end{array}$ \\
\hline
\end{tabular}

$t$ (Mean G/C for 0 to 2 hours compared with mean $G / C$ for 2 to 4 hours) 4.1 .

$t$ (Mean G/C for 2 to 4 hours compared with mean $G / C$ for 4 to 6 hours) 2.9 .

jority of subjects showed creatinine clearances within $130 \pm 25 \mathrm{ml}$. per minute.

If a comparison is to be made of the gelatin clearances in the various intervals in the same individual, or of those in same interval in the several subjects, it is necessary to nullify the effect of variations in renal functions. This nulli- fication can be accomplished by making use of ratio of the gelatin clearance to the creatinine clearance. This ratio multiplied by 100 is the gelatin clearance in percentage of the creatinine clearance. This value (expressed as $\mathrm{G} / \mathrm{C}$ in the charts) should be a measure of the relative ease of glomerular filtration of gelatin in any particular ex- 
periment as compared with a crystalloid, the clearance of which is supposed to be a measure of glomerular filtration. Though it is known that in man creatinine clearance is larger and more variable than the clearance of a substance like inulin which is not resorbed or excreted by the tubules, in an experiment such as this, where inulin clearances are too inconvenient to perform, creatinine clearances are probably satisfactory as measures of glomerular filtration.

There was a marked difference between the G/C values for heavy gelatin and those for light gelatin as seen in Tables IIIA, IIIB, and IIIC. For the former, for the 0 to 2 hour period, G/C ranged from 1.77 to 6.45 with an average of 3.93 , and a standard deviation of \pm 1.45 . For the 2 to 4 hour period, the average $\mathrm{G} / \mathrm{C}$ value was 2.95 , with a standard deviation of \pm 1.13 ; and for the 4 to 6 hour period the average was 2.78 and the standard deviation \pm 1.25 . The $t$ value when the mean $\mathrm{G} / \mathrm{C}$ for 0 to 2 hours was compared with the mean $\mathrm{G} / \mathrm{C}$ for 2 to 4 hours was 1.9 ; but for the comparison of the 2 to 4 hour and the 4 to 6 -hour periods, the $t$ value was 0.4 . Thus, for the heavy gelatin, though there appeared to be a progressive reduction in $\mathrm{G} / \mathrm{C}$ value during the 6 hour period following the end of the injection, the change was not significantly great.

On the other hand, in the case of the light gelatin, $\mathrm{G} / \mathrm{C}$ for the 0 to 2 -hour period was much higher. It ranged from 6.85 to 13.98 , and averaged 9.82, with a standard deviation of \pm 2.29 . There was a significant drop in $\mathrm{G} / \mathrm{C}$ values in the second period to an average of 5.64, and still further drop in the third 2-hour period to an average of 3.93. That these declines in $\mathrm{G} / \mathrm{C}$ values were genuine was seen from the $t$ values of 4.1 and 2.9. Thus, the light gelatin was much more readily excreted through the glomeruli than the

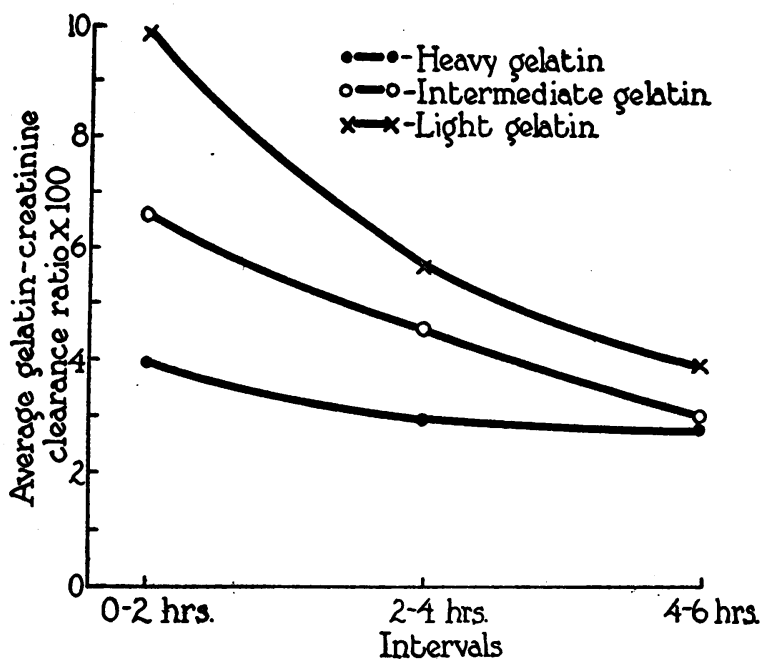

Fig. 2. Comparison of Average Gelatin-Creatinine Clearance Ratios in Three Successive 2-hour Periods After the Injection of Heavy, Intermediate, and Light Gelatins Respectively

heavy gelatin during the first 2 hours, but by the end of 6 hours, its relative clearance approached that of heavy gelatin (See Figure 2).

The intermediate gelatin, as indicated in the other data, showed a much greater variability in excretion, but the values appear to lie in between those of light gelatin and those of heavy gelatin. The mean $G / C$ values for the three periods and their respective standard deviations were $6.59 \pm$ $3.06,4.55 \pm 2.32$, and $3.01 \pm 0.99$. Here too, the progressive drop in $\mathrm{G} / \mathrm{C}$ until the values were in the range of those of heavy gelatin was apparent.

Plasma volume and the distribution of gelatin. Plasma volume determinations were made in only a few cases toward the end of the investigation. Determinations were made before the beginning of the experiment and at the end of the injection. The data in 8 cases, shown in Table $\mathrm{V}$, are too

TABLE IV

Water excretion and urinary gelatin concentrations for 6 hours following the intravenous injection of 5 per cent gelatin solution

\begin{tabular}{|c|c|c|c|c|c|c|c|c|c|}
\hline \multirow{2}{*}{$\begin{array}{c}\text { Type of gelatin } \\
\text { Lot nos. } \\
\end{array}$} & \multicolumn{5}{|c|}{ Light } & \multicolumn{2}{|c|}{ Heavy } & \multicolumn{2}{|c|}{ Intermediate } \\
\hline & 39 & 65 & 45 & 80 & 83 & 93 & $58-10$ & $58-15$ & 101 \\
\hline $\begin{array}{l}\text { Average water excretion to } 6 \text { hours } \\
\text { after injection, ml. } \\
\text { Maximal water excretion, ml. } \\
\text { Minimal water excretion, ml. } \\
\text { Maximal gelatin concentration, } \\
\text { grams per } 100 \mathrm{ml} \text {. }\end{array}$ & $\begin{array}{l}1538 \\
1780 \\
1345 \\
\\
3.42\end{array}$ & $\begin{array}{r}889 \\
1230 \\
510 \\
10.26\end{array}$ & $\begin{array}{r}621 \\
925 \\
317 \\
\\
12.06\end{array}$ & $\begin{array}{r}779 \\
1402 \\
272 \\
5.77\end{array}$ & $\begin{array}{r}445 \\
445 \\
445 \\
4.71\end{array}$ & $\begin{array}{r}955 \\
1577 \\
600 \\
\\
6.18\end{array}$ & $\begin{array}{r}835 \\
1493 \\
422 \\
\\
4.16\end{array}$ & $\begin{array}{r}846 \\
1542 \\
325 \\
\\
7.96\end{array}$ & $\begin{array}{r}1239 \\
1725 \\
325 \\
14.96\end{array}$ \\
\hline
\end{tabular}


TABLE V

Distribution of gelatin at the end of injection of 50 grams of gelatin

\begin{tabular}{|c|c|c|c|c|c|c|c|c|}
\hline Subject & Weight & $\begin{array}{l}\text { Gelatin type } \\
\text { and lot }\end{array}$ & $\begin{array}{l}\text { Initial plasma } \\
\text { volume }\end{array}$ & $\begin{array}{l}\text { Plasma vol- } \\
\text { ume at end } \\
\text { of injection }\end{array}$ & $\begin{array}{c}\text { Plasma } \\
\text { gelatin } \\
\text { concentration }\end{array}$ & $\begin{array}{c}\text { Total plasma } \\
\text { gelatin }\end{array}$ & $\begin{array}{l}\text { Total urinary } \\
\text { gelatin }\end{array}$ & $\begin{array}{l}\text { Total tissue } \\
\text { gelatin }\end{array}$ \\
\hline $\begin{array}{l}\text { D.C. } \\
\text { C.W. } \\
\text { P.W. } \\
\text { C.P. } \\
\text { J.R. } \\
\text { R.R. } \\
\text { J.C. } \\
\text { L.B. }\end{array}$ & $\begin{array}{c}\text { kgm. } \\
71 \\
50 \\
53 \\
55 \\
45 \\
74 \\
67 \\
50\end{array}$ & $\begin{array}{l}\text { Heavy } 93 \\
\text { Heavy } 93 \\
\text { Heavy } 93 \\
\text { Light } 45 \\
\text { Heavy } 93 \\
\text { Heavy } 93 \\
\text { Light } 39 \\
\text { Light } 39\end{array}$ & $\begin{array}{c}m l . \\
3333 \\
2000 \\
2424 \\
2410 \\
1887 \\
3125 \\
2778 \\
2062\end{array}$ & $\begin{array}{c}m l . \\
3846 \\
3030 \\
3571 \\
3125 \\
3704 \\
4273 \\
3680 \\
3555\end{array}$ & $\begin{array}{c}\text { grams per ml. } \\
0.929 \\
0.792 \\
0.684 \\
0.838 \\
0.741 \\
0.770 \\
0.593 \\
0.780\end{array}$ & $\begin{array}{l}\text { grams } \\
35.72 \\
24.00 \\
24.43 \\
26.19 \\
27.44 \\
32.90 \\
21.82 \\
27.73\end{array}$ & $\begin{array}{r}\text { grams } \\
6.20 \\
17.45 \\
8.88 \\
8.84 \\
6.89 \\
14.63 \\
18.24 \\
12.19\end{array}$ & $\begin{array}{r}\text { grams } \\
8.08 \\
8.55 \\
17.69 \\
14.97 \\
15.67 \\
2.47 \\
9.94 \\
10.08\end{array}$ \\
\hline Average & & & & & & 27.53 & 11.66 & 10.87 \\
\hline
\end{tabular}

meager for statistical analysis, but they at least show a trend. They demonstrate the well established hemodiluting effect of injected gelatin. From the plasma volume and the plasma gelatin concentration at the end of the injection, the total circulating gelatin could be calculated. Since the urinary gelatin during the period of injection was known, the difference between the sum of these factors and the total injected (taken as $\mathbf{5 0}$ grams in each case ${ }^{5}$ ) gave the amount of gelatin unaccounted for, which probably was in the interstitial fluids, since it was continuously excreted apparently unchanged during the following days. If the 8 cases were representative of all cases, then only some 55 per cent of the gelatin was still in the blood stream at the end of the injection, some 23 per cent had already been excreted, and some 22 per cent had been filtered off into the tissues. These findings are in close agreement with the findings of Little and Dameron (13), who demonstrated that, after a single injection of a Knox preparation of gelatin (labeled Lot number B 781 's) into normal dogs, only 50 per cent of gelatin was still present in the blood at the end of the injection and that 23 to 35 per cent had been excreted in the urine.

5 Analysis of the gelatin preparations showed the presence in all specimens of small but appreciable amounts of non-protein nitrogen which when subtracted from the total nitrogen often reduced the concentrations to slightly below 5 per cent. In addition to this error there was always an error due to loss of some solution in the preparation of the intravenous infusion. However both of these errors were at least partly annulled by the fact that the bottles contained slightly more than $1000 \mathrm{ml}$.

\section{DISCUSSION}

Analysis of the data for the plasma gelatin concentration, urinary gelatin excretions and gelatincreatinine clearance ratios for the three types of gelatin makes discernible a more or less consistent pattern in spite of great variability in the individual experiments. The higher $\mathrm{G} / \mathrm{C}$ values for the light gelatin in the first hours must be interpreted as being due to a larger proportion of more easily filterable molecules. These are about 10 per cent as readily filterable as creatinine through the glomeruli (and probably also through the general capillary endothelium). In the second and third 2-hour periods, there being a much smaller porportion of easily filterable molecules, the $\mathrm{G} / \mathrm{C}$ values drop considerably and approach those for the heavy gelatin experiments. In the later hours the clearances may be of the same order for all types, but the slightly higher plasma concentrations, plus possibly a slightly higher plasma volume, permit the compensatorily increased excretion of the heavy gelatin, so that eventually the total excretions are comparable.

The differences between the plasma gelatin concentrations fit in with this interpretation. With smaller excretions in the early period, and probably with similarly smaller transudations into the interstitial fluids, a relatively high plasma concentration is maintained for the heavy gelatin a longer time than for the light gelatin. Why this phenomenon is not demonstrable at the end of the injection is difficult to determine, but it probably has something to do with the relative amounts of hemodilution that occurred with the two types of gelatin. Unfortunately, an insufficient number of 
accurate plasma volume determinations were made in these experiments to permit a comparison between the heavy and light types.

An alternative interpretation of the progressive decline of the gelatin-creatinine clearance ratios presents itself, if one can make the unlikely assumption that gelatin is appreciably resorbed by the renal tubules. Pitts and Alexander (14), studying the renal resorptive mechanism of phosphate, showed that the phosphate-creatinine clearance ratios diminished as the plasma phosphate decreased, because the portion of filtered phosphate that was resorbed increased as less phosphate was filtered. To interpret the gelatin excretions on the same basis, one would have to postulate not only that gelatin is freely resorbed by tubules, but that resorption is the same for all sized molecules of gelatin. Neither of these postulates is likely. It is much more reasonable to assume that of molecules ranging in molecular weight from 20,000 to 80,000 , the smaller ones will be filtered more rapidly through the glomerular membranes, even if the molecules are elongated elipsoids with all nearly the same narrow diameter. This concept is further strengthened by the fact that when the ultracentrifuge pattern of the gelatin is narrow there is relatively little change in the successive $G / C$ values, and that the values for the three types of gelatin approach each other.

The magnitude of the gelatin clearance is surprising. Even in the case of heavy gelatin, absolute clearances ranging from 1.7 to 7.7 are much larger than might be anticipated from the knowledge of the behavior of a substance like serum albumin, the clearance of which in intact kidneys approaches 0 . The clearance of serum albumin even in nephrotic edema was found by Luetscher (15) to be only about 0.85 . The explanation for the difference in excretability of the two proteins is of course not a simple one, but one of the important factors must be the globoid shape of the albumin molecule, as contrasted with the elongated elipsoid character of the gelatin molecule.

That the gelatin concentration in the urine may reach 15 grams per $100 \mathrm{ml}$. indicates (See Table IV), as might be expected, that tubular resorption of water is not significantly deterred by the osmotic effect of gelatin, which effect is small compared with that of the crystalloids of the urine. Simi- larly high protein concentrations are not infrequently seen in severe cases of nephrotic syndrome associated with oliguria.

From a clinical point of view, the data point to at least a theoretical superiority of the heavy gelatin over the light gelatin. The plasma gelatin concentrations are maintained better in the case of heavy gelatin during the first few hours after the injection, which is the period of the desired clinical effect, whereas the ultimate excretion is as complete as in the case of the light gelatin. Furthermore the heavy gelatin injections are less likely to produce excessively high concentrations of gelatin in the urine, which might temporarily embarrass renal function. On the other hand, there is unequivocal evidence from this laboratory that the injection of light gelatin is clinically effective in shock and is innocuous. From a practical point of view there may be no appreciable difference between the two types. Surely one cannot extend the results of this study to attempt to prove that still heavier gelatin, the type that gels at room temperature, is for clinical purposes even better than the heavy gelatin utilized here, for many factors other than those discussed here, such as inconvenience of administration and danger of deposition in the tissues, must be taken into consideration.

\section{SUMMARY AND CONCLUSIONS}

1. The fate of intravenously injected gelatin was studied in 42 hospital control subjects to whom were administered $1000 \mathrm{ml}$. of 5 per cent gelatin. Though the solutions were all liquid at room temperatures, they were of three types: heavy, intermediate, and light. The weight average molecular weights were respectively of the order of $58,000,47,000$, and 37,000 .

2. The plasma gelatin concentration was highest at the end of the injection. It averaged 0.78 gram per $100 \mathrm{ml}$., and was the same for all three types. At 24 hours the plasma gelatin concentration had dropped to about 0.3 gram per $100 \mathrm{ml}$. for all three types. For the first six hours after the injection the plasma levels were maintained significantly higher in the heavy gelatin experiments. At 48 and 72 hours there were still appreciable quantities of gelatin in the plasma.

3. The urinary excretion of gelatin was markedly variable even with the same lot, but a pattern 
of excretion was discernible. The heavy gelatin excretion in 6 hours after the end of the injection averaged 14.68 grams, while the light was 22.72 grams. The intermediate gelatin values lay between these. By 72 hours, some 80 per cent of all types of gelatin was excreted. There was still further excretion on the fourth and fifth days. Thus it was unlikely that any considerable quantity of gelatin had been catabolized.

4. The average gelatin-creatinine clearance ratios were much higher for light gelatin than for heavy or intermediate gelatin. During the 3 successive 2-hour periods following the end of the injection, the ratios fell, but much more steeply for the light gelatin, so that at the end of 6 hours the ratios were all of the same order. This phenomenon was interpreted as indicating that the smaller gelatin molecules were rapidly excreted, leaving in the body molecules of the same order of excretability for all three types of gelatin.

5. No diuresis was seen after the injection of gelatin, except possibly where the gelatin was dissolved in 5 per cent dextrose. Concentrations of gelatin in the urine as high as 15 grams per 100 ml. were occasionally encountered which may produce a viscosity great enough to interfere temporarily with renal function. The lowest maximal urinary gelatin concentrations occurred in the heavy gelatin experiments.

6. Plasma volume determinations showed the well established hemodiluting effect of gelatin, and demonstrated that at the end of the injection only about 55 per cent of the gelatin was still in the blood stream, about 23 per cent having been excreted and 22 per cent filtered into the tissues.

7. These results indicate a theoretical clinical superiority of the heavy gelatin over the lighter types. Nevertheless light gelatin has been found to be clinically effective and innocuous in the treatment of shock.

The authors acknowledge gratefully the assistance of Miss Leah Gluck and Miss Bess Osgood with the chemical analyses, and of Mrs. Betty Vallancey, Miss Margaret Casella, and Mrs. Jeanne Hildebrandt with the infusions and collection of specimens.

\section{BIBLIOGRAPHY}

1. Kozoll, D. D., Popper, H., Steigmann, F., and Volk, B. W., The use of gelatin solutions in the treatment of human shock. Am. J. M. Sc., 1944, 208, 141.

2. Popper, H., Volk, B. W., Meyer, K. A., and Kozoll, D. D., Evaluation of gelatin and pectin solutions as substitutes for plasma in the treatment of shock. Arch. Surg., 1945, 50, 34.

3. Steigmann, F., Meyer, K. A., Kozoll, D. D., Volk, B. W., and Popper, H., Gelatin solution as plasma substitute. Am. J. Clin. Path., 1945, 15, 223.

4. Scatchard, G., Oncley, J. L., William, J. W., and Brown, A., Size distribution in gelatin solutions. Preliminary Report. J. Am. Chem. Soc., 1944, 66, 1980.

5. Koop, C. E., Fletcher, A. G., Riegel, C., and Lockwood, J. S., Gelatin as a plasma substitute. Surgery, 1944, 15, 839.

6. Janota, M., A rapid and simple technique for the determination of gelatin. J. Lab. and Clin. Med., 1943, 28, 1281.

7. Campbell, W. R., and Hanna, M. I., The albumin, globulins and fibrinogen of serum and plasma. $\mathrm{J}$. Biol. Chem., 1937, 119, 15.

8. Barbour, H. G., and Hamilton, W. F., The falling drop method for determining specific gravity. J. Biol. Chem., 1926, 69, 625.

9. Hoffman, W. S., Photelometric Clinical Chemistry. Wm. Morrow and Co., New York, 1941, p. 111.

10. Gregersen, M. I., A practical method for the determination of blood volume with the dye T-1824. J. Lab. and Clin. Med., 1944, 29, 1266.

11. Snedecor, G. W., Statistical Methods Applied to Experiments in Agriculture and Biology. Collegiate Press, Inc., Ames, Iowa, 1937.

12. Brunschwig, A., Scott, V. B., Corbin, N., and Moe, $R$., Observations on intravenous injection of gelatin for nutritional purposes. Proc. Soc. Exper. Biol. and Med., 1943, 52, 46.

13. Little, J. M., and Dameron, J. T., Plasma retention, urinary excretion and effect upon circulating total red cell volume of intravenous gelatin in normal dogs. Am. J. Physiol., 1943, 139, 438.

14. Pitts, R. F., and Alexander, R. S., The renal reabsorptive mechanism for inorganic phosphate in normal and acidotic dogs. Am. J. Physiol., 1944, $142,648$.

15. Luetscher, J. A., Jr., The effect of a single injection of concentrated human serum albumin on circulating proteins and proteinuria in nephrosis. J. Clin. Invest., 1944, 23, 365 . 